\title{
DEVELOPMENT OF A LITORINA BAY AT EPOO, NEAR PORVOO, SOUTHERN FINLAND
}

\author{
HEIKKI HAILA, KAARINA SARMAJA-KORJONEN and ANNELI UUTELA
}

\begin{abstract}
HAILA, HEIKKI, SARMAJA-KORJONEN, KAARINA and UUTELA, ANNELI, 1991: Development of a Litorina Bay at Epoo, near Porvoo, southern Finland. Bull. Geol. Soc. Finland 63, Part 2, 105-119.

A sediment sequence at Epoo, municipality of Porvoo, on the South coast of Finland, altitude $25 \mathrm{~m}$ a.s.1., was studied for Holocene shoreline displacement in the Baltic Sea basin. The sediment sequence is made up of sand, clay-gyttja and drift peat deposited during the Ancylus and Litorina stages of the Baltic Sea. Two cores of clay-gyttja with an intervening sand layer were analysed for diatoms and pollen. The composition of the diatom flora changes from typical fresh-water species of the Ancylus Lake to brackish-water flora indicating transition to the Litorina Sea.

The sequence shows a gradual change of a group of separate islands in the Ancylus Lake to larger complexes of dry land because of uplift. As two necks of land were formed, the site developed into a sheltered brackish-water bay, and drift peat accumulated. A radiocarbon age of $6130 \pm 50 \mathrm{yr}$ BP obtained from the top of the drift peat links the shore with the Litorina regression. The shore displacement history of the Helsinki-Porvoo area is discussed.
\end{abstract}

Key words: changes of level, Ancylus Lake, Litorina Sea, sediments, diatom flora, pollen diagrams, Holocene, Epoo, Porvoo, Finland.

Heikki Haila \& Kaarina Sarmaja-Korjonen: Division of Geology and Palaeontology, Department of Geology, University of Helsinki, Snellmaninkatu 3, SF-00170 Helsinki.

Anneli Uutela: Geological Survey of Finland, SF-02150 Espoo.

\section{Introduction}

A sediment sequence with pre-Ancylus, Ancylus and Litorina sediments, mainly gyttja-clays and sands, was found in a gravel pit at Epoo, near the town of Porvoo, southern Finland (Fig. 1). Such deposits have usually been studied from ancient bay basins which are now mires or lakes. The Epoo site, however, never formed an isolated basin and therefore retardation of the shoreline is here determined by the altitude ( $25 \mathrm{~m}$ a.s.1.) and the age of the uppermost brackish-water sedi- ment (drift peat).

The sediments at Epoo are exposed on dry land, which is rare in Finland and provides an exceptionally good opportunity to study the history of the Baltic Sea by analysing samples from a vertical section. This is particularly advantageous when thin beds, representing a short time span, are sampled for ${ }^{14} \mathrm{C}$ dating. It was also possible to take samples from under the sand layers.

Thanks to previous studies, shoreline displacement in the Porvoo area during the Litorina peri- 


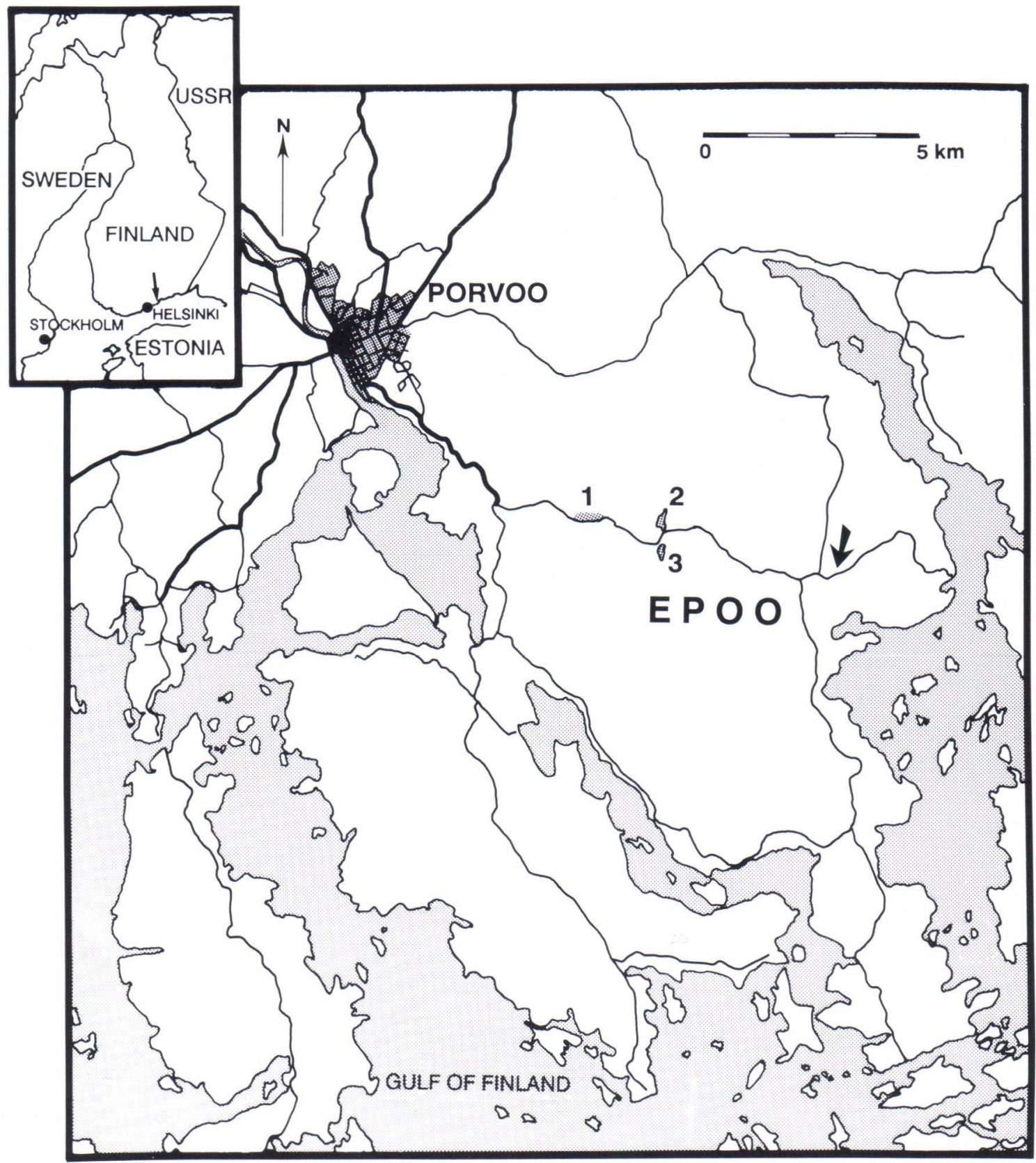

Fig. 1. The location of the study site at Epoo, municipality of Porvoo, southern Finland, some $50 \mathrm{~km}$ east of Helsinki. The study site is marked with an arrow. The numbers in the figure are the sites referred to in the text: $1=$ Bastuberg Bog (Eronen 1974), 2 = Lake Gåsgårdsträsket, 3 = Lake Malmträsket. 
od is relatively well known. Nevertheless some discrepancies have repeatedly been noticed when data on the Porvoo-Askola area and the neighbouring district in the west, Helsinki-Espoo, have been compared (Eronen 1974, 1983, Hyvärinen 1979,1980 ). These inconsistencies are usually associated with the Litorina transgression. It is not out of the question that such deviations are due to the differential movement of large bedrock blocks during glacioisostatic uplift, a process that still continues. The occurrence of a transitional and slightly saline substage, the Mastogloia Sea, between the fresh-water Ancylus and the saline Litorina stages, has also been discussed (Hyvärinen 1984, Hyvärinen et al. 1988).

The gravel pit at Epoo is in an esker running from northwest to southeast. The pit was about to be destroyed by the removal of sediment for a local golf course. The »rescue sampling» operation was carried out in March 1990 by Matti Saarnisto and Raimo Kujansuu of the Geological Survey of Finland. The stratigraphical record in this paper is based on the photographs and notes of Matti Saarnisto.

Of the three authors, Uutela studied the diatoms, Sarmaja-Korjonen made the pollen analyses and Haila investigated shore displacement and palaeogeography.

\section{Lithostratigraphy and laboratory techniques}

The site is located at $60^{\circ} 20^{\prime} 57^{\prime \prime} \mathrm{N}, 25^{\circ} 52^{\prime} 17^{\prime \prime} \mathrm{E}$ and is at an altitude of $25 \mathrm{~m}$ a.s.l. Part of the exposed sediment wall collapsed during sampling. Core II was taken about $15 \mathrm{~m}$ away from Core $\mathrm{I}$, as there was no difference in stratigraphy between these two sampling points. In the diagrams they are therefore presented as one. The lithostratigraphy (Fig. 2) was:

\section{$0-100 \mathrm{~cm}$ sand (removed)}

$100-140 \mathrm{~cm}$ clayey drift peat mixed with sand $140-160 \mathrm{~cm}$ gyttja-clay with pieces of wood $160-200 \mathrm{~cm}$ sulphide stained gyttja-clay
$200-235 \mathrm{~cm}$ $235-260 \mathrm{~cm}$ $260-280 \mathrm{~cm}$ $280-340 \mathrm{~cm}$ $340-385 \mathrm{~cm}$ black sulphide gyttja-clay gyttja-clay, an alder log at $250 \mathrm{~cm}$ blue gyttja-clay sand $\mathrm{cm}$ gyttja-clay, at $385 \mathrm{~cm}$ mixed with sand

below $385 \mathrm{~cm}$ glacial varved clay

The sediment succession at Epoo follows the general trend recognized in off-shore deposits of the Baltic Sea (Ignatius et al. 1981, Åker et al. 1988). Bottommost there are glacial varved clays. These are overlain by massive sulphide clays and these in turn by massive postglacial gyttja-clays. The intervening and covering sand layers that occur in the Epoo sequence are characteristic of a near shore depositional environment. The lithostratigraphy at Epoo and its relation to shoreline changes are discussed in the last chapter.

One cubic centimetre of sediment from every sampling depth was taken for diatom analysis. The organic matter was dispersed with hydrogen peroxide $\left(\mathrm{H}_{2} \mathrm{O}_{2}\right)$ for at least $4 \mathrm{~h}$ at $50-60^{\circ} \mathrm{C}$. The finer mineral matter was eliminated by discarding suspended clay before the coarse material was removed by decanting it $7-15$ times (Battarbee 1986).

The diatom taxonomy used here follows that of Hustedt (1930), Mölder and Tynni (1967$1973)$ and Tynni (1975-1980). Five hundred unbroken diatoms were counted from each sample. The diatoms were grouped ecologically (Mölder 1943, Miller 1964) and are presented in Fig. 3:

- Brackish-water and fresh-water diatoms. Diatoms requiring saline water were absent.

- Planktonic and littoral diatoms. Littoral diatoms include epiphytic and benthic diatoms.

The samples for pollen analysis were first boiled in $10 \%$ potassium hydroxide $(\mathrm{KOH})$ and afterwards sieved and decanted to remove any sand. Hydrofluoric acid (HF) treatment (Fægri \& Iversen 1975) was needed because the residual material was mainly clay. The samples were mounted in glycerin. 500 arboreal pollen (AP) grains were counted from every sample.

For the loss-on-ignition determinations the 


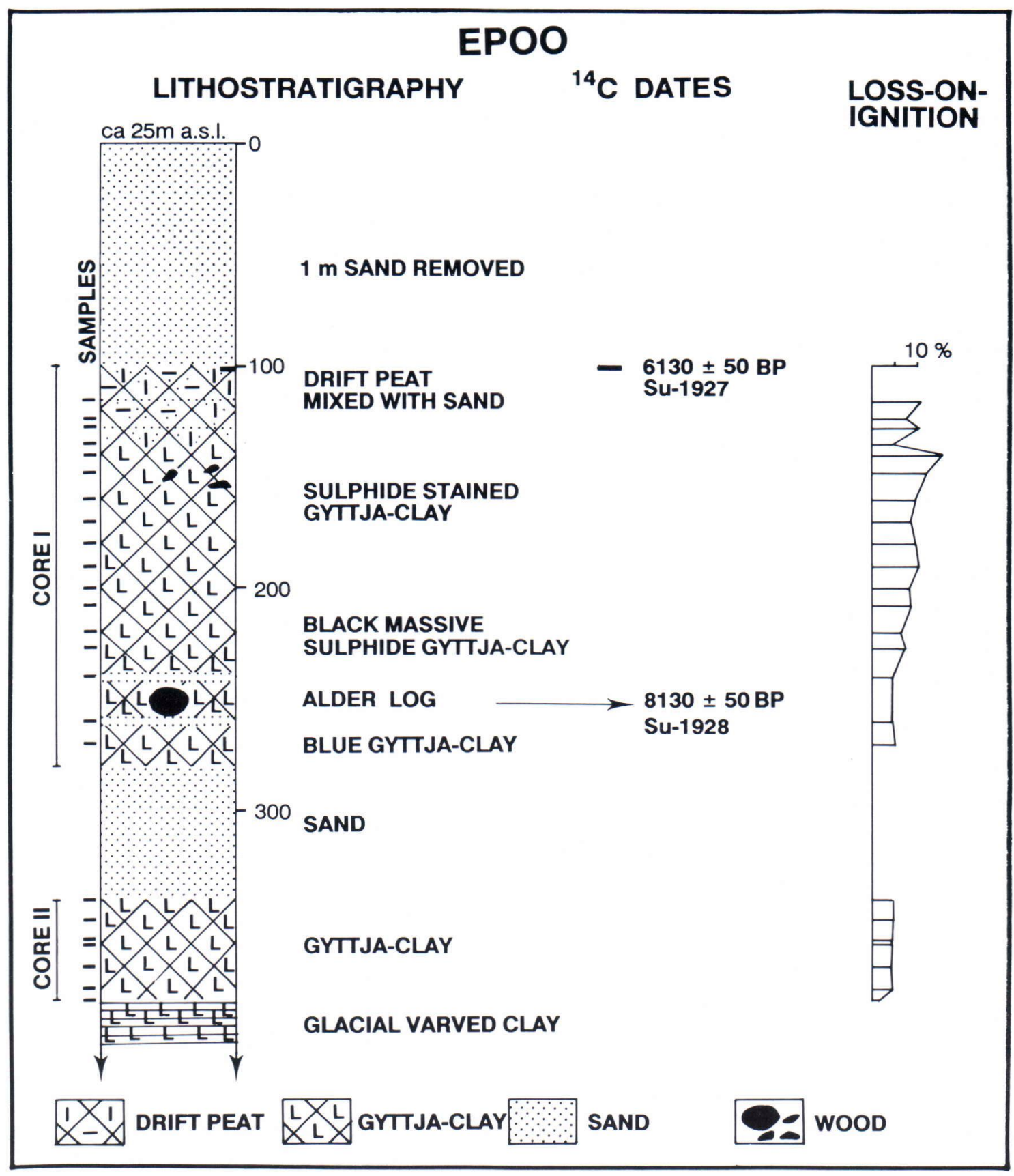

Fig. 2. Epoo, municipality of Porvoo, southern Finland. Lithostratigraphy, dates and loss-on-ignition curve.

samples were dried at $65^{\circ} \mathrm{C}$ over night and then heated at $550^{\circ} \mathrm{C}$ for $2 \mathrm{~h}$.

Two radiocarbon determinations were made by the Radiocarbon Laboratory of the Geological Survey of Finland. See also Fig. 2.

The organic drift peat sample (Su-1927) was 
sieved; and the $>1 \mathrm{~mm}$ fraction was used for dating. It was subjected to acid-alkali-acid treatment to remove carbonate or humic contaminants. The wood (Su-1928) was dated from the 30 youngest annual rings. The sample was reduced to cellulose, because it yields the most reliable dates on wood.

The results are as follows (see also Fig. 3):

Organic drift peat at a depth of $100-101 \mathrm{~cm}$, age $6130 \pm 50$ yr BP (Su-1927).

Alder wood at a depth of $250 \mathrm{~cm}$, age $8130 \pm$ 50 yr BP (Su-1928).

\section{Microfossil record}

\section{Diatom Stratigraphy}

\section{Core II $(385-340 \mathrm{~cm})$}

The general character of the diatom flora succession of the Epoo section is shown in Fig. 4. At $385 \mathrm{~cm}$, from where lowermost sample of Core II was taken, the diversity of diatoms was low, and many frustules were broken. The dominant species is Melosira arenaria $(66.0 \%)$, which indicates sandy in-shore deposits. Melosira islandica + var. helvetica, Diploneis domblittensis, Epithemia hyndmannii, E. turgida and Gyrosigma attenuatum are also present. The composition is typical of Ancylus flora (Miller 1964, Eronen 1974, Alhonen et al. 1978, Ignatius \& Tynni 1978, Eronen \& Haila 1982).

The diatom flora becomes more heterogeneous upwards and the number of species increases. The proportion of Melosira arenaria decreases drastically from $19.6 \%(380 \mathrm{~cm})$ to $4.2 \%(358$ $\mathrm{cm}$ ). Gyrosigma attenuatum and Diploneis domblittensis are common. Epithemia hyndmannii is also present as are Opephora martyi and Stephanodiscus astraea. All are species of Ancylus flora.

Over $96 \%$ of the diatom species indicate a fresh-water environment. Although planktonic species are abundant (max. $31.6 \%$ at a depth of $349 \mathrm{~cm}$ ), littoral species form the dominant group. Thus the flora indicates the littoral facies of a large lake, i.e. the Ancylus Lake.

\section{Core I $(270-116 \mathrm{~cm})$}

The diatom flora of the lower part of Core I again consists of the diatoms typical of a large fresh-water lake (the Ancylus flora). This flora is exceedingly rich, containing 109-141 different species. Up to $200 \mathrm{~cm}$, Melosira islandica and $M$. islandica var. helvetica dominate, Epithemia turgida and E. zebra being almost as abundant. Stephanodiscus astraea and Epithemia sorex are also common. About half of the flora is planktonic.

Epithemia spp. dominates between 190 and 170 $\mathrm{cm}$. At $190 \mathrm{~cm}$ there are many exceptionally asymmetric Epithemia frustules, suggesting that conditions were no longer ideal for Epithemia species. The proportion of Melosira specimens decreases, and Stephanodiscus astraea and Epithemia sorex are common. The flora becomes slightly more homogeneous, and 91 different species were recorded. To start with littoral species are dominant but they gradually diminish to $52.8 \%$.

At $160 \mathrm{~cm}$, there are maxima of Fragilaria constricta $+F$. pinnata $(4.4 \%)$ and Rhoicosphaenia curvata $(7.4 \%)$. The littoral species increase again until they constitute two-thirds of the flora, but only 56 taxa are present.

At $148 \mathrm{~cm}$, Epithemia spp. is again dominant $(80.6 \%)$. The species indicating brackish-water (e.g. Diploneis smithii, Navicula peregrina and Rhabdonema arcuatum) become slightly more abundant. Mastogloia baltica, M. braunii and M. smithii appear in minor quantities, probably indicating the beginning of the Mastogloia stage, which can usually only be identified in littoral facies (Eronen 1974, Ignatius et al. 1981). The littoral species constitute $94.2 \%$ of the flora. The number of taxa increases to 69 .

At $140 \mathrm{~cm}$, the proportion of brackish-water species suddenly rises to $31.8 \%$, with a sharp maximum of Mastogloia spp. (20.0\%). The other 


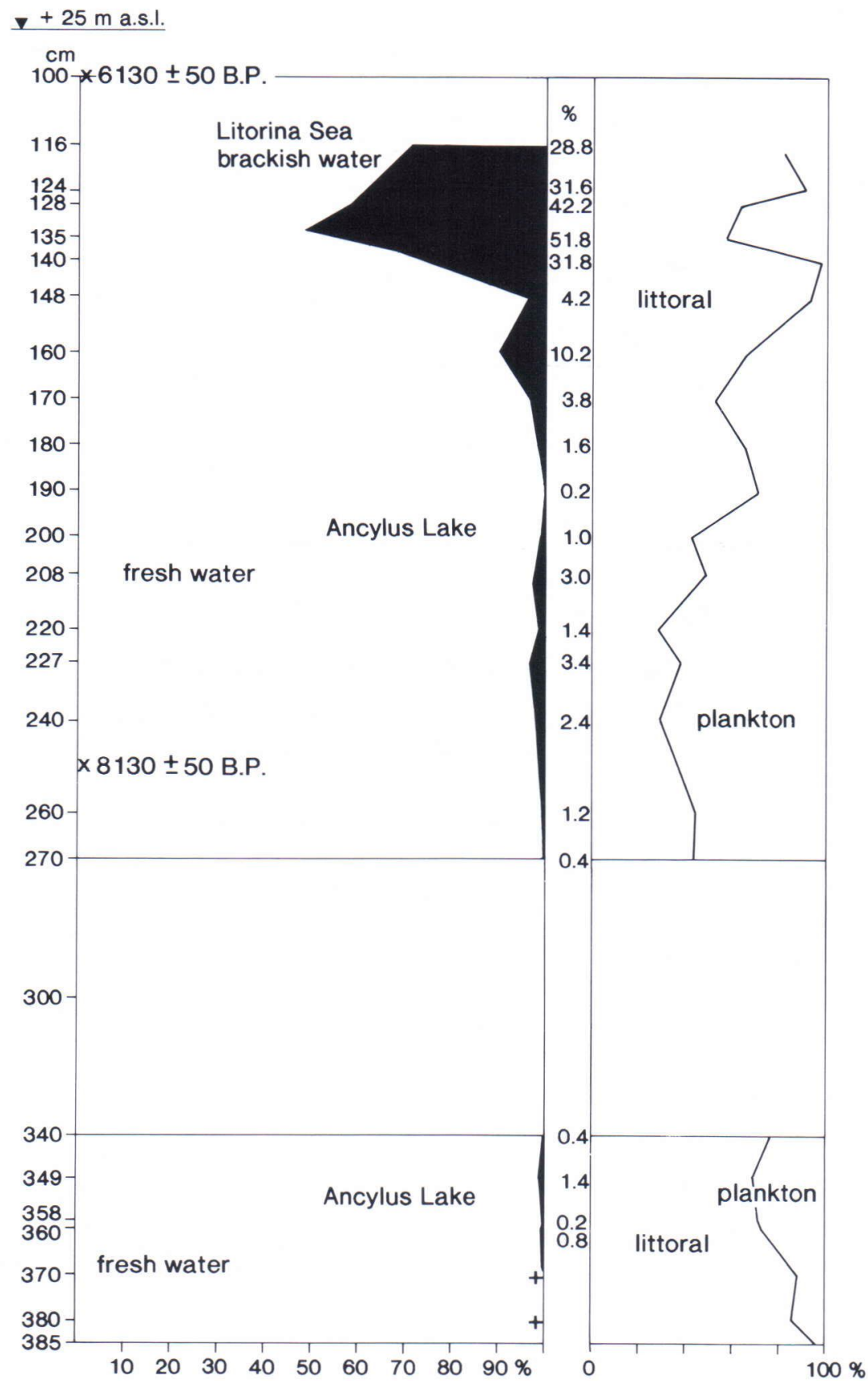

Fig. 3.. Epoo, municipality of Porvoo, southern Finland. Ecological assemblages of diatoms. Important fresh-water species are: Melosira arenaria, M. islandica + var. helvetica, Epithemia hyndmannii, Gyrosigma attenuatum and Stephanodiscus astraea. The main brackish-water species are mainly: Melosira moniliformis, M. juergensi, Mastogloia braunii, M. elliptica + var. dansei, M. smithii, Campylodiscus clypeus, C. echeneis and Diploneis interrupta. Species which live in a littoral environment are: Melosira arenaria, M. juergensi, Epithemia spp., Gyrosigma attenuatum, Campylodiscus clypeus, C. echeneis, Diploneis interrupta and Mastogloia spp. Planktonic species are: Melosira islandica + var. helvetica, M. moniliformis and Stephanodiscus astraea. 


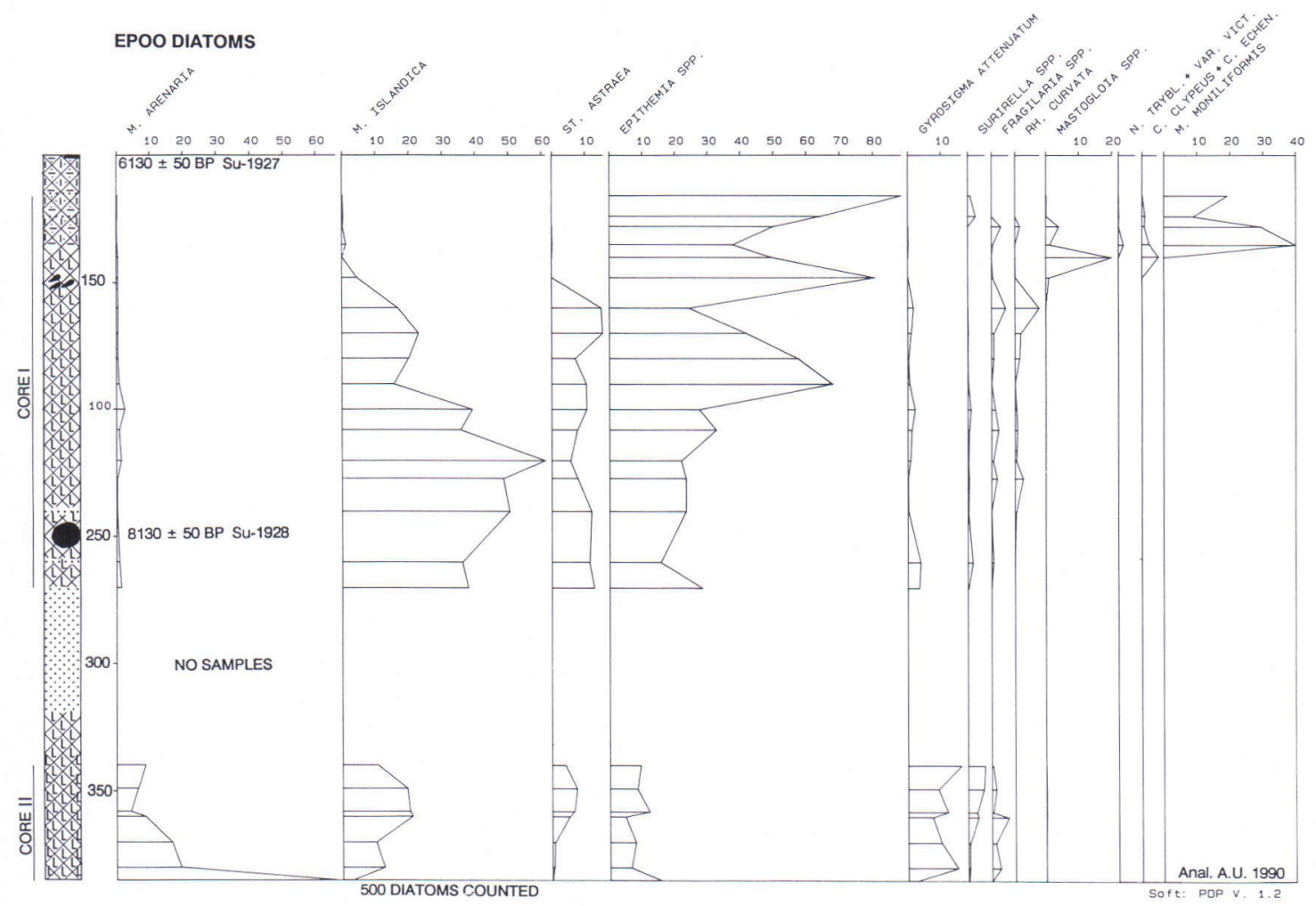

Fig. 4. Epoo, municipality of Porvoo, southern Finland. Relative diatom diagram. Only selected species are drawn. The Su-1928 date was determined from a $\log$ of alder found at $250 \mathrm{~cm}$. The abbreviations of diatom families are : M. = Melosira, St. = Stephanodiscus, Rh. = Rhoicosphaenia, N. = Nitzschia and C. = Campylodiscus. Sediment symbols as in Fig. 2.

dominant species are Epithemia turgida and $E$. sorex $(49.8 \%)$. At this level there is also a peak of Campylodiscus clypeus (3.0\%) and C. echeneis $(1.6 \%)$. Littoral species account for $99.4 \%$ of the flora.

At $135 \mathrm{~cm}$, the brackish-water species are at their most abundant (51.8\%), especially Melosira moniliformis (40.0\%). Melosira juergensi, Campylodiscus echeneis, Cocconeis scutellum, Mastogloia elliptica, Nitzschia tryblionella var. victoriae, Surirella striatula and Synedra tabulata are also present. Melosira islandica and Stephanodiscus astraea disappear. About half of the flora belongs to the littoral facies of the brackish-water environment.

In the uppermost samples $(128-116 \mathrm{~cm})$ brackish-water flora make up $30 \%$. The abun- dance of littoral species varies, but does not account for more than half of the flora.

\section{Pollen stratigraphy}

\section{Core II $(385-340 \mathrm{~cm})$}

The pollen spectra of Core II (Fig. 5) are totally dominated by Pinus, which constitutes over $90 \%$ of AP in most of the samples. Betula is present, as are Alnus, Corylus and Ulmus, but the pollen grains of all of these, except Betula were corroded and faded. The non-arboreal pollen (NAP) flora consists of Poaceae, Chenopodiaceae and Artemisia along with Cyperaceae. Polypodiaceae spores abound. 


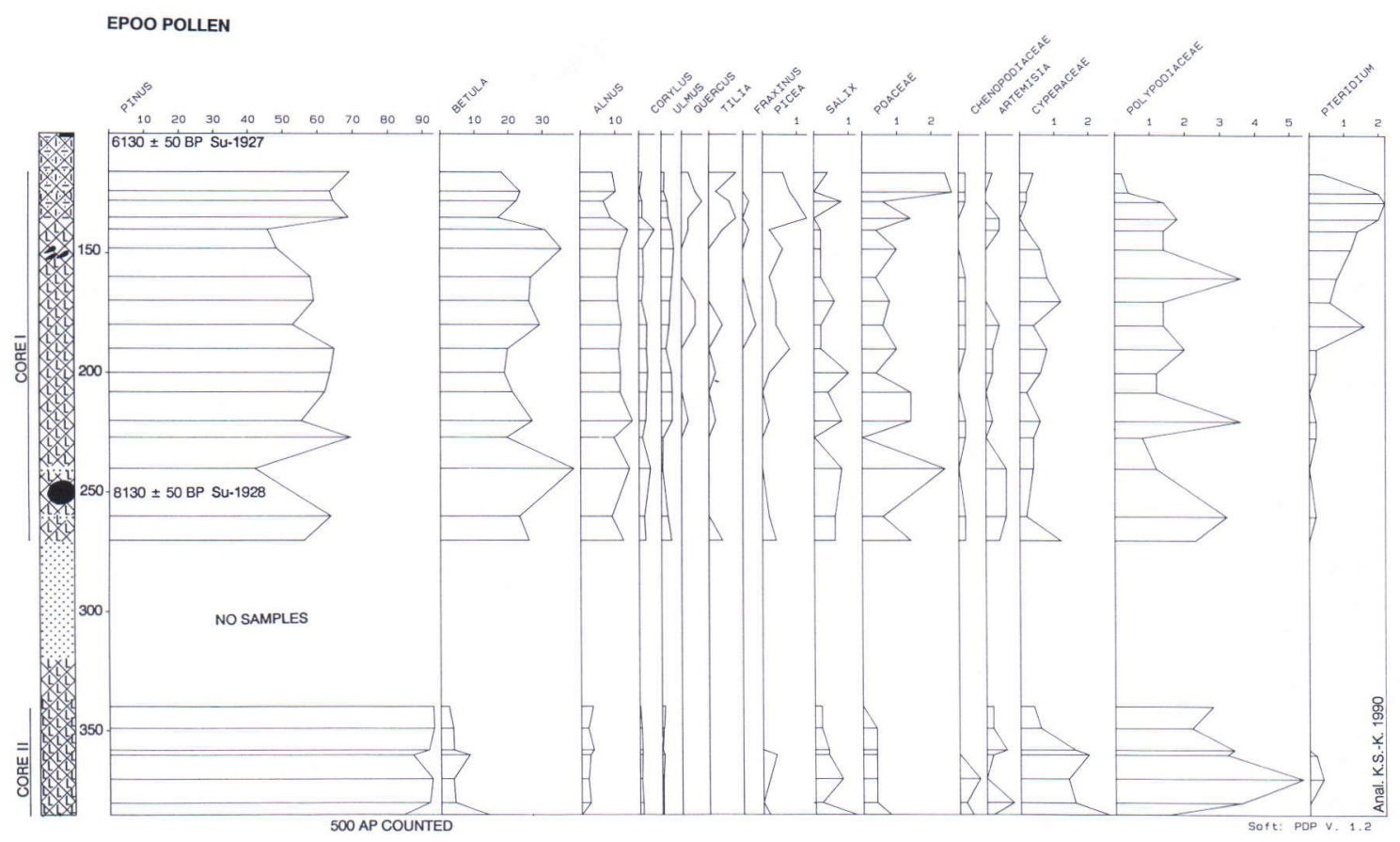

Fig. 5. Epoo, municipality of Porvoo, southern Finland. Relative pollen diagram. The Su-1928 date was determined from a $\log$ of alder found at $250 \mathrm{~cm}$. Sediment symbols as in Fig. 2.

\section{Core I $(270-116 \mathrm{~cm})$}

The dominance of Pinus continues, but not so totally, now reaching about 50-60\%. Betula and Alnus pollen grains are abundant, the former with an abundance of about $20-30 \%$ and the latter with about $10 \%$. The curves of Corylus and Ulmus are continuous, but Quercus, Tilia and Fraxinus are present more sporadically. The curve of Tilia becomes continuous at $140 \mathrm{~cm}$. The NAP flora is about the same as in Core II. Pteridium spores increase towards the top, reaching $2 \%$ in the three topmost samples.

\section{Conclusions}

\section{Core II}

The diatom flora of Core II refers to a large lake, i.e. the Ancylus Lake. A shallow-water facies is indicated by the dominance of littoral spe- cies. The sand layer between Core I and Core II (Fig. 2) can also be attributed to decreasing water depth and wave washing. According to the pollen record, Core II represents the Pine Zone (V) of southern Finland (Donner 1971) with a total dominance of Pinus pollen. Most of the pollen grains of Alnus, and all of those of Corylus and Ulmus in these samples were corroded and faded and were presumably redeposited. The presence of an Ancylus Lake diatom flora and a Pinus pollen maximum together with insignificant Alnus values suggests that these spectra represent the time at about $9000-8500 \mathrm{yr}$ BP.

\section{Core I}

According to the diatom stratigraphy, up to $140 \mathrm{~cm}$, most of Core I consists of Ancylus sediments. The diatoms indicate a shallowing facies up to $140 \mathrm{~cm}$, where the Mastogloia spp. appear, with a peak of $20 \%$. This may allude to the 
Mastogloia stage. The Mastogloia spp. are also known from fresh-water littoral environments close to carbonate sediments and limestone bedrock (Mölder \& Tynni 1973), but none of these have been recorded from the Porvoo district (Laitala 1964).

At $135 \mathrm{~cm}$, the abundance of brackish-water species is $51.8 \%$, with a maximum of Melosira moniliformis and other brackish-water species indicating the beginning of the Litorina Sea phase.

The diatom stratigraphy of the Epoo sequence closely resembles that of Kvarnträsk in Espoo and of Lippajärvi in Vantaa (Hyvärinen 1984). After the fresh-water species of the Ancylus phase, there is a marked peak of Mastogloia spp. followed by the sudden appearance of the brackish to saline water species Campylodiscus clypeus, C. echeneis and Melosira moniliformis.

The maximum of Campylodiscus spp. (4.6\%) remains insignificant compared with that at Bastuberg (Eronen 1974) near the Epoo site, at Gallträsket in Kauniainen (Alhonen 1972) or at Kuttulampi in Espoo (Hyvärinen 1982), where Campylodiscus accounts for $15-60 \%$ of the diatoms. The scarcity of this benthic lagoonal species at Epoo may be due to the exposure, which was more open than in the typical Clypeus lagoons mentioned above.

The pollen spectra of Core I can be placed biostratigraphically in the Birch-Alder-Hazel-Elm Zone (VI-VIII) (Donner 1971). The dominance of Pinus (50-60\%) is atypical of small lake sediment records and must reflect the sedimentary environment, i.e. a littoral environment in which waves gathered floating masses of Pinus pollen.

The spread of Alnus is not seen in the diagram, as Core II and I are separated by a sand layer from which no samples were taken. The processes forming the sand layer may also have eroded the topmost sediments of Core II. At the beginning of the upper part (Core I) of the diagram, Alnus is already present as an established constituent of the vegetation, with its pollen amounting to about $10 \%$. The date of a piece of alder log from $250 \mathrm{~cm}, 8130 \pm 50 \mathrm{yr} \mathrm{BP}(\mathrm{Su}-1928)$, also shows that Alnus was present in the Porvoo district at this time.

There are two ways to explain the Tilia curve, which seems to be the key to the dating of the upper part of the pollen diagram. First, a sea coast is an unsteady depositional environment, and pollen sedimentation and transport are controlled by the depth of the water and the distance from forests. Therefore the spread of Tilia to the Porvoo district could be seen as an echo at $200 \mathrm{~cm}$, the depth at which the first well preserved Tilia pollen grain was found. Eronen (1974, p. 134) has reported a date of $7250 \pm 250 \mathrm{yr}$ BP for Tilia ${ }^{\circ}$ (the beginning of the continuous Tilia curve) from Bastuberg, some five kilometres west of the Epoo site (see also Aartolahti 1967 and Tolonen \& Ruuhijärvi 1976).

However, the fact that most previous studies from the Espoo-Helsinki-Porvoo area (e.g. Alhonen 1972, Eronen 1974, Hyvärinen 1984) have a clear Tili $^{\circ}$ horizon analysed from similar material, i.e. gyttja-clay and clay-gyttja, from environments just as unsteady as that at Epoo, renders this explanation questionable.

The second and the most likely alternative is that the Tilia ${ }^{\circ}$ horizon should be placed at 140 $\mathrm{cm}$, where the Tilia curve becomes continuous. The Tilia ${ }^{\circ}$ horizon is most probably not synchronous on the south coast of Finland (Tolonen \& Ruuhijärvi 1976). It also depends on the methods of pollen analysis used, i.e. the number of pollen grains counted, the interval between the samples analysed and the edaphic characteristics of the area. It is often contemporary with the appearance of the brackish-water diatom species of the Litorina stage at about 7500-7200 yr BP. In the Epoo sequence the Litorina diatom flora appears at $140 \mathrm{~cm}$ (Fig. 4).

Sedimentation must have been rather rapid between 270 and $140 \mathrm{~cm}$ (Core I) which thus covers the time span of about $8200-7200 \mathrm{yr}$ BP. Deposition of only $40 \mathrm{~cm}$ of sediments between 7200 and $6100 \mathrm{yr}$ BP seems improbable and suggests that there is a hiatus near the top of the sediment sequence. The sand layers in the drift peat also 
point to unsteady sedimentation conditions and to the possibility that a gap exists between the organic surface (about $6100 \mathrm{yr} \mathrm{BP}$ ) and the Tilia ${ }^{\circ}$ horizon (about 7200 yr BP).

\section{The Litorina transgression in the Porvoo, Helsinki and Stockholm areas}

The data on the Epoo sequence are in good agreement with the general concept of the shore displacement for the Porvoo area. The relative chronology there has earlier been studied by e.g. Hyyppä (1937), Virkkala (1953), Sauramo (1958), Tynni (1960, 1966). The interpretations rely on pollen and diatom analyses and on shoreline data. Diagrams with absolute dates have been published by Hyyppä et al. (1962) Tynni (1966), Eronen (1974) and Matiskainen (1989a).

A Litorina site often referred to, and only about $5 \mathrm{~km}$ west of the present study area, is the Bastuberg bog (Fig 1), which has been studied by Eronen (1974; see also Hyyppä et al. 1969). It forms the basis for the shoreline displacement curves constructed for the Porvoo area (Eronen 1974, 1983; see also Eronen 1976 and Matiskainen 1989b). The basin was almost isolated at 8480 \pm 190 yr BP (Hel-394) and the flooding waters of the Litorina transgression reached its threshold (28.5 m a.s.1.) at about $7250 \pm 240 \mathrm{yr}$ BP (Hel-392). The final isolation occurred at around $6230 \pm 220$ yr BP (Hel-391). The diatom stratigraphy supports the chronology.

The two small lake basins also marked on the map (Fig. 1) have a threshold altitude a couple of metres lower than that of the Bastuberg bog (Lake Gåsgårdsträsket $25 \mathrm{~m}$ a.s.l. and Lake Malmträsket $22.7 \mathrm{~m}$ a.s.1.). No unequivocal evidence for isolation before the onset of the Litorina transgression has been found (Eronen 1983). The radiocarbon-dated isolation contacts of these neighbouring basins clearly indicate that the regressive sea level was at about $24 \mathrm{~m}$ a.s.l. $5600-5700{ }^{14} \mathrm{C}$ years ago.

Detailed research on the Litorina transgression in the Helsinki region has been carried out in re- cent years by Hyvärinen (1979, 1980, 1982, 1984; see also Hyvärinen \& Eronen 1979 and Hyvärinen et al. 1988). According to him, the Litorina stage began soon after $7500 \mathrm{yr}$ BP and the peak of the transgression was reached at about 7000 yr BP. He states further that the transgression can be distinguished only in the area east of Helsinki or in the area with isobases lower than 3 $\mathrm{mm}$ for the present annual uplift (the assumed eustatic rise of $0.8 \mathrm{~mm} \mathrm{yr}^{-1}$ is included).

Findings at variance with this conclusion have been published by Hyyppä $(1937,1950)$, Eronen (1974) and Alhonen et al. (1978). In the vicinity of Askola, a municipality about $25 \mathrm{~km}$ northwest of Porvoo, a Litorina transgression with an amplitude of a couple of metres has been reported on isobases higher than $3 \mathrm{~mm} / \mathrm{a}$ (refers to the Litorina shore at about 30-32 m a.s.1.) (Virkkala 1953, Tynni 1966).

Matiskainen (1989b) restudied some of the basins in the Askola region but could not recognize any clear Litorina transgression extending above $32 \mathrm{~m}$ a.s.l. Ristaniemi and Glückert (1988) have traced and dated the Litorina transgression in Bastukärr bog, southwestern Finland, at an altitude of about $38 \mathrm{~m}$ a.s.l.

These conflicting interpretations may be due to the fact that during a period of nearly stagnant shore line even small local deviations from a regular uplift pattern may produce signs of transgression (Eronen 1974, Nuñez 1978, Hyvärinen 1979). A contemporaneous change from fresh to brackish water conditions causes a drastic change in the diatom flora, which may further confuse interpretations. Temporary high water levels caused by storms and events such as threshold erosion also result in changes in the littoral and lagoonal sedimentation facies (Hyvärinen 1980, 1984).

A preliminary shoreline displacement curve constructed for the Stockholm region by Miller (in Brunnberg et al. 1985) shows a double-peaked Litorina transgression reaching over $50 \mathrm{~m}$ a.s.l. with an amplitude of several metres. In a shoreline displacement curve by Risberg (1991) the 
Fig. 6. Epoo, municipality of Porvoo, southern Finland. Palaeogeographical map showing the zones of different altitudes. The zones can be linked with the shore displacement of the area and the development of the study site from an archipelago to a sheltered bay. The study site is marked with an arrow.

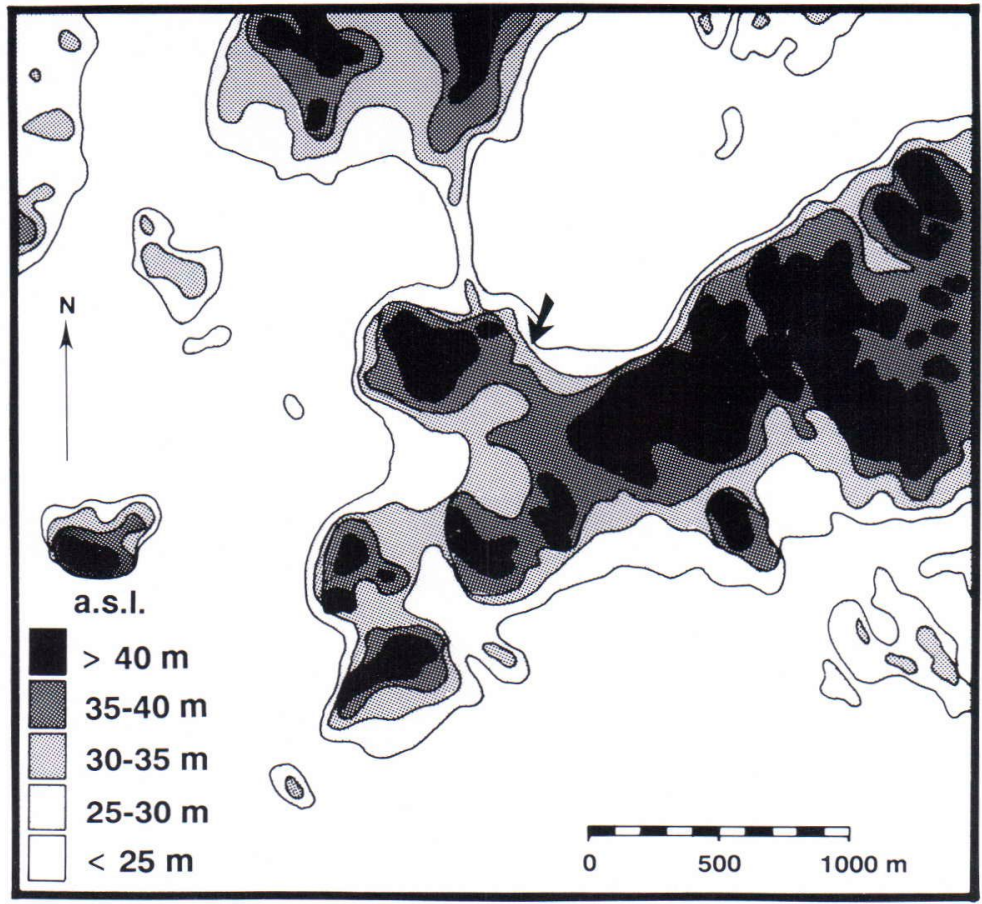

a.s.l. between 10200 and 9600 yr BP. By about 9300 yr BP the shoreline then had risen by about $10 \mathrm{~m}$ as a consequence of the Ancylus transgression, reaching a level of $50 \mathrm{~m}$ a.s.1. The Ancylus regression, following the culmination of the transgression, started vigorously, slowing down at about $8500 \mathrm{yr} \mathrm{BP}$, when the water level had fallen to some $30 \mathrm{~m}$ a.s.l.. In time, this corresponds to the start of the ingression of oceanic water into the Baltic basin, first into Mecklenburg Bay. The Mastogloia transgression started between 8500 and $8000 \mathrm{yr}$ BP in the southern Baltic Sea (e.g. Eronen et al. 1990).

At Epoo the sea water level may have stagnated or turned into a slow transgression towards the end of that period. No clear proof of this early rise in sea level in southern Finland has been reported. At Epoo the shore level was most likely between 30 and $25 \mathrm{~m}$ a.s.1. from 8000 to 6000 yr BP. The peak of the Litorina transgression, which reached an altitude of about $28 \mathrm{~m}$ a.s.1., took place at around $7000 \mathrm{yr}$ BP.
The Yoldia regression was rapid, lowering the water level at Epoo from about 75 to 40 metres 


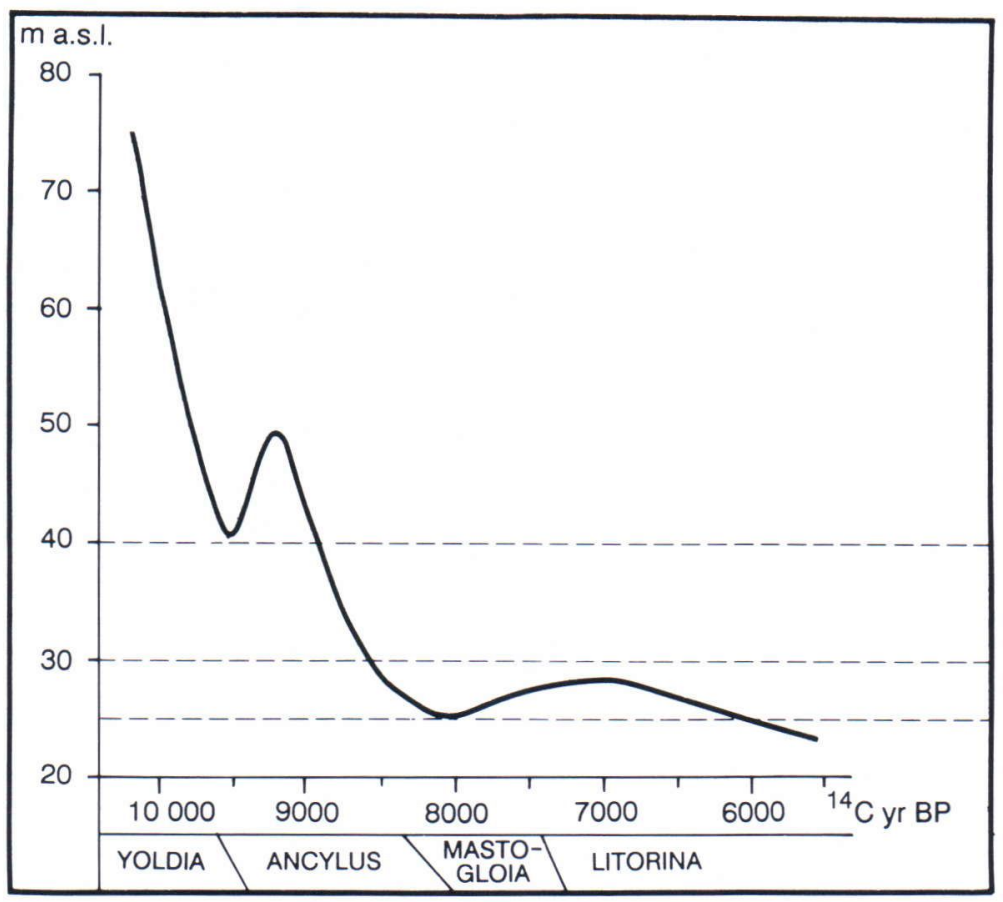

Fig. 7. Tentative shore displacement curve for the $28 \mathrm{~m}$ Litorina Sea isobase in the Epoo area. The curve is based on the present material and on the curves and Baltic Sea stage boundaries presented by Eronen $(1976,1983)$.

\section{The palaeogeographical development at Epoo}

The succession described above is compatible with the stratigraphy at the Epoo site (Fig. 2). The stratified (varved) clay, referring to the proximity of the retreating ice front, at the bottom of the section was most probably deposited during the Yoldia stage (lasting from about 10200 to 9600 yr BP in southern Finland). It could be even older if an erosive phase causing a hiatus existed during the low water level (c. $40 \mathrm{~m}$ ) stage close to the minimum of the Yoldia regression. No analyses were made on this basal layer. The conclusions drawn of the origin of the varved clay gain support when the overlying »blue clay» is examined. Both the pollen and diatom data (Figs. 3 and 4) on this stratum indicate a rapid regressive phase of the Ancylus Lake starting at 9300 yr BP and continuing to $8500 \mathrm{yr}$ BP (strong dominance of Pinus pollen and presence of $\gg$ Ancylus flora»).

The main topographical features of the surroundings of the site are presented in Fig. 6 . The crucial points are the sandy "thresholds» northwest and southwest of the pit. These sills, which form part of an esker, played a major role during the change of the environment from an archipelago to a sheltered Litorina bay.

The sand layer at $340-270 \mathrm{~cm}$ might be attributed to a lowering of the water level to such an altitude (slightly above $35 \mathrm{~m}$ a.s.l.) that the southern sandy »threshold» of the forming bay (Fig. 6) was intensely eroded. An age of around $8700 \mathrm{yr}$ BP is referred for this event. Abrupt changes in the biostratigraphy suggest that there may have been a gap in the deposit, most probably at the top of the blue gyttja-clay (Fig. 2). The deposition of the sand layer may have been quite drastic because of the rapid regression of the water level (as much as $5 \mathrm{~m} /$ century).

After the change in the sedimentary environment from open water conditions into a calm bay, a sequence of gyttja-clay rich in sulphide and plant macrofossils with intervening sand layers was deposited. The time interval is about $8500-$ 
$6000 \mathrm{yr} \mathrm{BP}$, which refers to the Mastogloia and Litorina Seas. It is not known exactly when the slowing regression culminated, turning into a weak transgression in this region. The amplitude of the Mastogloia-Litorina transgression here was only a couple of metres.

The connections with a larger water body via the western »threshold» (Fig. 6) of the bay must have dominated the hydrography of the area during the time span $8500-6000$ yr BP. The presence of black sulphide clay in the off-shore sediments (Ignatius et al. 1981) has been attributed to a fundamental change in hydrographic conditions. Such a change, believed to indicate a pronounced increase in salinity, does not explain the existence of sulphide clay at Epoo. Here the diatom spectra representing the time in question clearly reflect fresh-water conditions. It is possible that the formation of sulphide was postdepositional. The radiocarbon-date of the log of Alnus $(8130 \pm 50 \mathrm{yr} \mathrm{BP})$ is the oldest age of alder wood ever recorded in Finland. It gives an age of about $8000 \mathrm{yr}$ BP for the lower boundary of the sulphide clay $(250 \mathrm{~cm})$.

The immigration of the brackish-water diatom flora occurred at a depth of about $140 \mathrm{~cm}$. Some $10 \mathrm{~cm}$ deeper, weak impulse of the Mastogloia

\section{References}

Aartolahti, T., 1967. Die Datierung der $\mathrm{T}^{\circ}$-Grenze. Fennia 97, 12-30.

Aker, C., Eriksson, B., Grönlund, T. \& Kankainen, T., 1988. Sediment stratigraphy in the nothern Gulf of Finland. Geological Survey of Finland, Special Paper 6, 101-117. Alhonen, P., 1972. Gallträsket: The geological development and palaeolimnology of a small polluted lake in southern Finland. Soc. Sci. Fennica, Comm. Biol. 57, 34 p. -, Eronen, M., Nuñez, M., Salomaa, R. \& Uusinoka, R., 1978. A contribution to Holocene shore displacement and environmental development in Vantaa, South Finland: the stratigraphy of Lake Lammaslampi. Bull. Geol. Soc. Finland 50, 69-79.

Battarbee, R.W., 1986. Diatom analysis. In Berglund, B.E. (Ed.): Handbook of Holocene palaeoecology and palaeohydrology, 527-570. Wiley \& Sons, Chichester. phase can be distinguished. The start of the rational curve of Tilia coincides well with the start of the »true» Litorina stage. Both events are commonly dated to be slightly older than 7000 yr BP in southern Finland. The peak of the Litorina transgression close to that date and the following drop in water level leading to a shallow littoral environment caused disturbances in the uppermost part of the sediment sequence as a result of erosion and redeposition.

The sea level fell below $25 \mathrm{~m}$ a.s.l. soon after the deposition of the sandy drift peat at about $6000 \mathrm{yr}$ BP. This is consistent with the data on the neighbouring basins (Fig. 1) according to which the sea level was at about $28 \mathrm{~m}$ a.s.l. at $6200 \mathrm{yr} \mathrm{BP}$ and at $24 \mathrm{~m}$ a.s.l. at $5600-5700 \mathrm{yr}$ BP. The topmost sand horizon deposited in a beach environment, possibly during a storm.

Acknowledgements. Professors Matti Saarnisto and Raimo Kujansuu took the samples and suggested that we carry out this research. Dr Risto Tynni and Dr Tuulikki Grönlund gave useful advice about diatom analyses. Tuovi Kankainen and her staff determined the radiocarbon dates and Liisa Ikonen identified the dated wood. Satu Moberg drew Figure 4. We thank all these persons for their help.
Brunnberg, L., Miller, U. \& Risberg, J., 1985. Project eastern Svealand: development of the Holocene landscape. Iskos 5, 85-91.

Donner, J., 1971. Towards a stratigraphical division of the Finnish Quaternary. Comm. Phys. Mathem. 41, $281-305$.

,- 1980 . The determination and dating of synchronous late Quaternary shorelines in Fennoscandia. In Mörner, N.A. (Ed.): Earth rheology, isostasy and eustasy, 285-293. Wiley \& Sons, Chichester.

- \& Eronen, M., 1981. Stages of the Baltic Sea and late Quaternary shoreline displacement in Finland. Excursion guide. Inqua subcommision on shorelines of northwestern Europe. (Excursion in southern Finland with a symposium at Lammi biological station 9-14. September 1981). University of Helsinki, Department of Geology, Division of Geology and Paleontology. Stencil 5, 53 p.

Eronen, M., 1974. The history of the Litorina Sea and as- 
sociated Holocene events. Comm. Physico-Math. 44, $79-195$ + supplement.

,- 1976 . A radiocarbon-dated Ancylus transgression site in southeastern Finland. Boreas 5, 65-76.

-, 1983. Late Weichselian and Holocene shore displacement in Finland. In Smith, D. E. \& Dawson, A. G., (eds): Shorelines and isostasy, 183-207. Institute of British geographers, Special Pulication 16, Academic Press, London.

— \& Haila, H., 1982. Shoreline displacement during the Ancylus Lake stage near Helsinki, South Finland. Ann. Acad. Sci Fennicae, A III. 132, 111-129.

—, Ristaniemi, O.\& Lange, D., 1990. Analysis of a sediment core from the Mecklenburg bay, with a discussion on the early Holocene history of the southern Baltic Sea. Geol. Fören. Stockholm Förh., 112, 1-8.

Fagri, K. \& Iversen, J., 1975. Textbook of pollen analysis. Munksgaard, Copenhagen, 295 p.

Hustedt, F., 1930. Bacillariophyta (Diatomeae). In Pascher, Die Süsswasser-flora Mitteleuropas. Heft 10, 466 p.

Hyvärinen, H., 1979. Helsingin seudun rannansiirtyminen Litorina-aikana Sipoosta tutkitun näytesarjan valossa. (Bakunskärrsträsket: a stratigraphical site relevant to the Litorina shore displacement near Helsinki). Terra 91, $15-20$.

—, 1980. Relative sea-level changes near Helsinki, southern Finland, during early Litorina times. Bull. Geol. Soc. Finland 52, 207-219.

,- 1982 . Interpretation of stratigraphical evidence of sea-level history: a Litorina site near Helsinki, southern Finland. Ann. Acad. Sci. Fenn. A. III. 134, 139-149.

-, 1984. The Mastogloia Stage in the Baltic Sea history: diatom evidence from southern Finland. Bull. Geol. Soc. Finland 56, 99-115.

-, Donner, J., Kessel, H. \& Raukas, A., 1988. The Litorina sea and Limnea sea in the northern and central Baltic. In Donner, J. \& Raukas, A. (Eds.): Problems of the Baltic Sea history, 25-35. Ann. Acad. Sci. Fennicae A III, $148 \mathrm{p}$.

— \& Eronen, M., 1979. The Quaternary history of the Baltic. The northern part. In Gudelis, V. \& Königsson, L.K. (Eds.): The Quaternary history of The Baltic, 7-27. Acta Universitatis Upsaliensis, Symposia Universitatis Upsaliensis, Annum Quingentesimum Celebrantis 1. Uppsala.

Hyyppä, E., 1937. Post-glacial Changes of Shore-line in South Finland. Bull. Comm. Geol. Finlande 120, 225 p.

—, 1950. Helsingin ympäristö. Maaperäkartan selitys, 53 p. Geologinen tutkimuslaitos. Helsinki.

—, Hoffrén, A. \& Isola, A., 1962. Geological Survey of Finland, Radiocarbon measurements I. In Flint, R.F. \& Deevey, E.S. (Eds.): Radiocarbon 4, 81-83.

-, Heikkinen, A.\& Toivonen, V., 1969. Geological Survey of Finland, Radiocarbon measurements IV. In Deevey, E.S., Flint, R.F., Odgen, J.G. III \& Rouse, I. (Eds.):
Radiocarbon 11, 153-168.

Ignatius, H. \& Tynni, R., 1978. Itämeren vaiheet ja piilevätutkimus. Turun yliopiston maaperägeologian osaston julkaisuja 36, 26 p.

—, Axberg, S., Niemistö, L. \& Winterhalter, B. 1981. Quaternary Geology of the Baltic Sea. In Voipio, A. (Ed.): The Baltic Sea, 54-104. Elsevier.

Laitala, M., 1964. Geological map of Finland. Pre-Quaternary rocks. Sheet 3021 Porvoo. 1:100 000. Geological Survey of Finland.

Matiskainen, H., 1989a. The chronology of the Finnish Mesolithic. In Bonsall, C. (Ed.): Mesolithic in Europe, 379-390. John Donald Publishers LTD. Glasgow.

Matiskainen, H., 1989b. The palaeoenvironment of Askola, southern Finland. Mesolithic settlement and subsistence $10000-6000$ B.P. Iskos 8, 1-97.

Miller, U., 1964. Diatom floras in the Quaternary of the Göta River valley (Western Sweden). Sveriges Geologiska Undersökning, Ser Ca, Avhandlingar och uppsatser I 4:0, $\mathrm{Nr} 44,67 \mathrm{p}$.

Mölder, K. 1943. Studien über die Ökologie und Geologie der Bodendiatomeen in der Pojo-Bucht. Ann. Bot. Soc. Zool.-Bot. Fennicæ Vanamo 18, 204 p.

—, Valovirta, V.\& Virkkala, K., 1957. Über Spätglazialzeit und frühe Postglazialzeit in Südfinnland. Bull. Comm. Géol. Finlande 178, 1-49.

— \& Tynni, R., 1967-1973. Über Finnlands rezente und subfossile Diatomeen I-VII. I: Bull. Comm. géol. Finlande 29,199-207 (1967). II: Bull. Geol. Soc. Finland 40, 151-170 (1968). III: ibid. 41, 235-251 (1969). IV: ibid. 42, 129-144 (1970). V: ibid. 43, 203-220 (1971), VI: ibid. 44, 141-149 (1972). VII: ibid. 45, 159-179 (1973).

Nuñez, M., 1978. A model to date Stone Age sites within an area of abnormal uplift in southern Finland. Iskos 2, $25-51$.

Risberg, J., 1991. Palaeoenvironment and sea level changes during the early Holocene on the Södertörn peninsula, Södermanland, eastern Sweden. Stockholm University, Department of Quaternary Research. Report 20.

Ristaniemi, O. \& Glückert, G., 1987. The Ancylus transgression in the area of Espoo - the first Salpausselkä, southern Finland. Bull. Géol. Soc. Finland 59, 45-69.

—, 1988. Ancylus- ja Litorinatransgressiot Lounais-Suomessa. In Lappalainen, V. \& Papunen, H., (Eds.), Tutkimuksia geologian alalta, Turun Yliopiston julkaisuja, Sarja C. Osa $67,129-145$.

Sauramo, M., 1954. Das Rätsel des Ancylussees. Geologiche Rundschau 42, 197-233.

-, 1958. Die Geschichte der Ostsee. Ann. Acad. Sci. Fennicae A III, 51, 522p.

Tolonen, K. \& Ruuhijärvi, R., 1976. Standard pollen diagrams from the Salpausselkä region of Southern Finland. Ann. Bot. Fennici 13, 155-196.

Tynni, R., 1960. Ostseestadium während der Allerödzeit in 
Askola, Ost-Uusimaa (Südfinland). Bull. Comm. Géol. Finlande 188 (12), 149-167.

—, 1966. Über spät- und postglaziale Uferverschiebung in der Gegend von Askola, Südfinland. - Bull. Comm. Géol. Finlande 223, 97 p.

-, 1975-1980. Über Finnlands rezente und subfossile Diatomeen VIII-XI. VIII: Bull. Geol. Surv. Finland 274, 55p (1975). IX: ibid. 284, 37 p. (1976). X: ibid. 296, 55 p. (1978). XI: ibid. 312,93 p. (1980).
Valovirta, V., 1965. Zur spätquartären Entwicklung SüdostFinnlands. Bull. Comm. Géol. Finlande 220, 1-101.

Virkkala, K. 1953. Altitude of the Littorina limit in Askola, Southern Finland. Bull. Comm. Géol. Finlande 159, $59-71$.

Received March 29, 1991

Revision accepted September 10, 1991 